\title{
Epidemiological study of congenital malformations at birth in a tertiary health centre in central India
}

\author{
Manuja Naik ${ }^{1 *}$, Meena Bhargava², Kalpana Yadav²
}

\begin{abstract}
${ }^{1}$ Department of Obstetrics and Gynecology, Bangalore Medical College and Research Institute, Karnataka, India
${ }^{2}$ Department of Obstetrics and Gynecology, Shyam Shah Medical College, Rewa, Madhya Pradesh, India
\end{abstract}

Received: 22 February 2018

Revised: 30 March 2018

Accepted: 30 April 2018

\author{
*Correspondence: \\ Dr. Manuja Naik, \\ E-mail: manuja.naik05@gmail.com
}

Copyright: () the author(s), publisher and licensee Medip Academy. This is an open-access article distributed under the terms of the Creative Commons Attribution Non-Commercial License, which permits unrestricted non-commercial use, distribution, and reproduction in any medium, provided the original work is properly cited.

\begin{abstract}
Background: The proposed study was carried out to determine incidence of congenital malformations, incidence of $\mathrm{CM}$ in live and still births, risk factors attributable, maternal and perinatal outcome, to frame the recommendations for early detection and prevention of CM.

Methods: Prospective observational study. The cases selected from those attending the antenatal O.P.D. and those admitted in wards of Obs and Gynae Dept., GMH who delivered congenitally malformed baby dated from August 2013-July 2014. A detailed history, examination, relevant investigations was done.

Results: Out of 9014 deliveries, 110 babies had CM. The incidence of CMs was found to be $1.22 \%$. Maximum number $(24.55 \%)$ of CM s were of CNS, most common was NTD (Anencephaly). Incidence of CMs was more in still births, mothers of age $>40 \mathrm{yrs}$ and $<20 \mathrm{yrs}$, of illiterate, educated $<8$ std., house wives, rural areas, unbooked and multigravida. Most CM fetuses were delivered prematurely (67.27\%). CVS and CNS systems were more commonly involved in consanguinous married couples. CM was associated with drug intake, $1.82 \%$ on antiepileptics, $1.82 \%$ on antihypertensives, $3.64 \%$ on oral hypoglycaemics, $0.91 \%$ on NSAID, $6.36 \%$ on unspecified drugs. $12.73 \%$ CMs were seen in passive smokers, $6.36 \%$ consumed alcohol, $17.27 \%$ pan/gutka intake. Majority were delivered by vaginal route, maximum fetuses $(82.73 \%)$ were in vertex presentation, maximum (67.27\%) CMs were in male babies.

Conclusions: Many malformations arise because of the interplay of genetic, environmental and multifactorial factors. The stress imposed may be reduced considerably by understanding the causes of the malformations and adopting the management strategies outlined for the prevention or reduction of CM.
\end{abstract}

Keywords: Consanguineous, Congenital malformations, Genetic

\section{INTRODUCTION}

Congenital Malformations (CM), defined as a morphological defect of an organ, part of an organ, resulting from an internally abnormal developmental process. ${ }^{1}$ Congenital anomalies affect around 1 in 33 infants and result in approximately 3.2 million birth defect related disabilities every year. An estimated 2,70,000 newborn die during the first 28 days of life every year from congenital anomaly. ${ }^{2}$ Incidence of congenital anomalies in India is around $1.2-1.6 \% .^{3-6}$ Congenital anomaly account for $8-15 \%$ perinatal deaths and $13-16 \%$ of neonatal deaths in India. ${ }^{7,8}$ According to joint World Health Organization (WHO) and MOD meeting report, birth defects account for $7 \%$ of all neonatal mortality and 3.3 million under five deaths. ${ }^{9}$

In India birth defects prevalence varies from 64.3/1000 live births. ${ }^{9}$ According to March of Dimes (MOD) Global report on birth defects, worldwide 7.9 million births 
occur annually with serious birth defects and 94\% of these births occur in the middle and low income countries. ${ }^{10}$ Major birth defects include congenital heart defects, neural tube defects (NTDs) and Down syndrome, hemoglobinophathies and glucose-6-phosphate dehydrogenase deficiency, cause $20 \%$ of infant mortality and are responsible for a substantial number of childhood hospitalizations. ${ }^{11}$

Birth Defect Registry of India (BDRI) show that the common systems involved in birth defects are Central Nervous System (CNS), Musculoskeletal System (MSS) and Cardiovascular System (CVS). ${ }^{12}$

\section{Causes and risk factors}

Although $50 \%$ of all congenital anomalies (CA) cannot be linked to a specific cause, there are some known risk factors. The common causes of CAs can be grouped into genetic, environmental and multifactorial. ${ }^{13}$

Socioeconomic factors: This is an indirect determinant, common in middle- and low-resource countries, where mothers are susceptible to macronutrient and micronutrient malnutrition, advanced maternal age, exposure to alcohol and infections. ${ }^{2}$

Genetic factors: Consanguinity increases the prevalence of CA.

Infections: Maternal infections such as syphilis, toxoplasma, cytomegalovirus, herpes simplex, and rubella are a significant cause of CAs. ${ }^{2}$

Maternal health status: Iodine deficiency, folic acid insufficiency, overt diabetes mellitus, maternal age, lack of immunization against rubella, unplanned pregnancies also contribute. ${ }^{14,2}$

Environmental factors: Maternal exposure to pesticides, medications, alcohol, tobacco, and other psychoactive substances, certain chemicals, retinoids, high doses of radiation, working or living near or in waste sites, smelters or mines also contribute.

\section{Importance}

The importance of congenital malformations is as follows.

1. Deaths from CMs are increasing over the decades. These are the first killer of infants under one year of age, approximately forty percent of early fetal deaths are supposed to be due to malformations. ${ }^{15}$

2. CMs are the $2^{\text {nd }}$ most common consumer of pediatric hospital beds. ${ }^{16}$

3. Economic and psychological burdens of parents with malformed babies are beyond all imagination.
4. There has been increasing interest in CMs, with many reports on phocomelia due to thalidomide and on German measles syndrome.

5. Affected individuals suffer from serious physical, mental and social consequences of their handicap. This influences families, community in terms of quality of life, need for services and health care costs.

CMs are etiologically considered as the outcome of interaction between host and environment. This indicates the importance and urgency of epidemiological investigations in this field.

\section{METHODS}

It was a retrospective observational study. Ethics approval was obtained.

The cases will be selected from those attending the antenatal O.P.D. and those admitted in wards of OBGYN Dept., GMH who delivered congenitally malformed baby dated from August 2013 to July 2014. A detailed history taken, examination done and relevant investigations were done.

\section{Inclusion criteria}

Inclusion criteria were patient with antenatally USG diagnosed congenital malformation; patients delivering congenitally malformed babies in labor room; all high risk mothers who can have congenitally malformed baby; all fresh and macerated still births with risk of congenital malformations.

\section{Exclusion criteria}

Exclusion criteria were babies aged more than 1 week.

\section{RESULTS}

The present study includes 9014 women who delivered babies over a period of $1 \mathrm{yr}$. among them, 110 babies had CMs. In the present study, the incidence of CMs at birth was found to be $1.22 \%$ (110).

In the present study, Incidence of CMs were more in still births $(8.17 \%)$ than live births $(1.02 \%)$ and this distribution was found statistically significant.

The study shows, maximum women with congenital malformations were in the age group of $>40$ years $(8.33 \%),<20$ yrs were $5.88 \%$ and least were seen in the age group of $31-40$ yrs $(0.42 \%)$. The distribution was found statistically significant $\left(\mathrm{p}=0.000, \mathrm{X}^{2}=23.173\right.$ ).

The congenital malformations were more common in Muslim religion $(3.40 \%)$ than in Hindu religion (1.15\%) $\left(\mathrm{p}=0.003, \mathrm{X}^{2}=9.019\right)$. 
Table 1: Incidence of congenital malformations among live births and still births in SGMH.

\begin{tabular}{|lllll|}
\hline Birth status & No. of deliveries & $\begin{array}{l}\text { No. of congenital } \\
\text { malformations present }\end{array}$ & $\begin{array}{l}\text { No. of congenital } \\
\text { malformations absent }\end{array}$ & Percentage (\%) \\
\hline Live births & 8696 & 89 & 8607 & 1.02 \\
\hline Still births & 318 & 21 & 297 & 8.17 \\
\hline Total & 9014 & 110 & 8904 & \\
\hline$\left(\mathrm{p}=0.000, \mathrm{X}^{2}=74.689\right)$ & & &
\end{tabular}

The CMs were common in multigravida (1.64) than in primigravida (0.94).

Table 2: Distribution of congenital malformations according to age and religion $(n=9014)$.

\begin{tabular}{|llll|}
\hline \multicolumn{2}{|l|}{$\begin{array}{l}\text { No. of } \\
\text { deliveries }\end{array}$} & $\begin{array}{l}\text { No. of } \\
\text { congenital } \\
\text { malformations }\end{array}$ & Percentage \\
\hline Age in yrs & & & \\
\hline$\leq 20$ & 34 & 2 & 5.88 \\
\hline $21-30$ & 7066 & 99 & 1.40 \\
\hline $31-40$ & 1902 & 8 & 0.42 \\
\hline$\geq 40$ & 12 & 1 & 8.33 \\
\hline Religion & & & 1.15 \\
\hline Hindu & 8750 & 101 & 3.41 \\
\hline Muslim & 264 & 9 & \\
\hline
\end{tabular}

Table 3: Distribution of congenital malformations by parity $(n=9014)$.

\begin{tabular}{|llll|}
\hline Parity & $\begin{array}{l}\text { No. of } \\
\text { deliveries }\end{array}$ & $\begin{array}{l}\text { No. of } \\
\text { congenital } \\
\text { malformations }\end{array}$ & Percentage \\
\hline Primi & 5409 & 51 & 0.94 \\
\hline Multi & 3605 & 59 & 1.64 \\
\hline Total & 9014 & 110 & \\
\hline
\end{tabular}

$\left(\mathrm{p}=0.004, \mathrm{X}^{2}=8.071\right)$

In the present study, women from rural area (1.34\%) and unbooked $(1.46 \%)$ had maximum number of congenital malformations than urban area $(0.47 \%)$ and booked
$(0.39 \%)$. This distribution was found statistically significant.

Table 4: Distribution of congenital malformations according to residential and booking status $(n=9014)$.

\begin{tabular}{|c|c|c|c|}
\hline & $\begin{array}{l}\text { No. of } \\
\text { deliveries }\end{array}$ & $\begin{array}{l}\text { No. of } \\
\text { congenital } \\
\text { malformations }\end{array}$ & Percentage \\
\hline \multicolumn{4}{|l|}{ Residence } \\
\hline Rural & 7728 & 104 & 1.34 \\
\hline Urban & 1286 & 6 & 0.47 \\
\hline \multicolumn{4}{|c|}{ Booking status } \\
\hline Booked & 2030 & 8 & 0.39 \\
\hline Unbooked & 6984 & 102 & 1.46 \\
\hline
\end{tabular}

Table 5: Distribution of cong. Malf.s according to risk factor exposure in present pregnancy $(n=110)$.

\begin{tabular}{|lll|}
\hline Risk factor & $\begin{array}{l}\text { No. of } \\
\text { congenital } \\
\text { malformations }\end{array}$ & Percentage \\
\hline Fever & 10 & 9.09 \\
\hline Folic acid not taken & 81 & 73.64 \\
\hline Drug intake & 9 & 8.18 \\
\hline DM & 4 & 3.64 \\
\hline HTN & 2 & 1.82 \\
\hline Epilepsy & 2 & 1.82 \\
\hline Rh incompatibility & 2 & 1.82 \\
\hline Total & 110 & 100 \\
\hline
\end{tabular}

Table 6: Distribution of congenital malformations observed in consanguineous marriages (n=11).

\begin{tabular}{|c|c|c|c|}
\hline & Congenital malformations & No. of congenital malformations & Percentage \\
\hline \multirow{8}{*}{$\begin{array}{l}\text { consanguineous } \\
\text { marriage }\end{array}$} & PDA & 3 & 2.73 \\
\hline & VSD & 2 & 1.82 \\
\hline & Hydrocephalus, Encephalocele & 1 & 0.91 \\
\hline & Absence of distal forearm and hand & 1 & 0.91 \\
\hline & Imperforate Anus & 1 & 0.91 \\
\hline & Hydronephrosis & 1 & 0.91 \\
\hline & TGA, PS & 1 & 0.91 \\
\hline & Trisomy D & 1 & 0.91 \\
\hline \multicolumn{2}{|c|}{ Non consanguineous marriage } & 99 & 90.0 \\
\hline & Total & 110 & 100 \\
\hline
\end{tabular}


Table 7: Distribution of congenital malformations by antenatal intake of drugs $(n=110)$

\begin{tabular}{|c|c|c|}
\hline $\begin{array}{l}\text { Drugs/medications } \\
\text { taken during } \\
\text { pregnancy }\end{array}$ & $\begin{array}{l}\text { No. of } \\
\text { congenital } \\
\text { malformations }\end{array}$ & Percentage \\
\hline OHD* & 4 & 3.64 \\
\hline Anti epileptic & 2 & 1.82 \\
\hline Anti hypertensive & 2 & 1.82 \\
\hline Not known & 8 & 7.27 \\
\hline Others & 7 & 6.36 \\
\hline NSAID** & 1 & 0.91 \\
\hline None & 86 & 78.18 \\
\hline Total & 110 & 100 \\
\hline
\end{tabular}

In the present study, among various risk factors studied, 9.09\% (10) women had fever, 73.64\% (81) women didn't take Folic Acid, $1.82 \%$ (2) were Hypertensive and 3.64\% (4) with diabetes mellitus, $8.18 \%$ (9) were taking drugs in present pregnancy, 2 (1.82\%) with Epilepsy, 2 (1.82\%) with Rh incompatibility.

In the present study, $3(2.73 \%)$ women delivered babies with PDA, $2(1.82 \%)$ with women delivered babies with VSD and others like absence of distal forearm, Imperforated Anus, Hydronephrosis, TGA with PS and Trisomy D were one babies each.

Table 8: System wise distribution of congenital malformations according to ICD-10 chapter XVII $(n=110)$.

\begin{tabular}{|llll|}
\hline & Body system & $\begin{array}{l}\text { No. of } \\
\text { congenital } \\
\text { malformations }\end{array}$ & Percentage \\
\hline $\begin{array}{l}\text { Q } \\
00-07\end{array}$ & Nervous system & 27 & 24.55 \\
\hline $\begin{array}{l}\text { Q } \\
80-89\end{array}$ & Others & 26 & 23.64 \\
\hline $\begin{array}{l}\text { Q } \\
35-45\end{array}$ & $\begin{array}{l}\text { Digestive } \\
\text { system }\end{array}$ & 21 & 19.09 \\
\hline $\begin{array}{l}\text { Q } \\
20-28\end{array}$ & Cvs & 15 & 13.64 \\
\hline $\begin{array}{l}\text { Q } \\
65-79\end{array}$ & $\begin{array}{l}\text { Musculoskeletal } \\
\text { system }\end{array}$ & 14 & 12.73 \\
\hline $\begin{array}{l}\text { Q } \\
10-18\end{array}$ & $\begin{array}{l}\text { Ear, Eyes, Face, } \\
\text { Neck }\end{array}$ & 4 & 3.64 \\
\hline $\begin{array}{l}\text { Q } \\
60-64\end{array}$ & Urinary system & 2 & 1.82 \\
\hline $\begin{array}{l}\text { Q } \\
50-56\end{array}$ & Genital system & 1 & 0.91 \\
\hline & Total & 110 & 100 \\
\hline
\end{tabular}

In the present study, 4 (3.64) were on oral hypoglycaemics, $2(1.82 \%)$ were taking antiepileptic drugs, $2(1.82 \%)$ were taking anti hypertensives. 8 $(7.27 \%)$ women with congenitally malformed babies don't know whether they were taking any drug. 7 $(6.36 \%)$ were taking drugs but don't know what drugs they were taking. $1(0.91 \%)$ was taking NSAID.

Table 9: Types of congenital malformations $(n=110)$.

\begin{tabular}{|c|c|c|}
\hline Tyрe & No. & Percent \\
\hline NTD & 27 & 24.55 \\
\hline CHD & 15 & 13.64 \\
\hline Tracheo oesophageal fistula & 7 & 6.36 \\
\hline Dduodenal atresia & 6 & 5.45 \\
\hline Imperforate anus & 4 & 3.64 \\
\hline Diaphragmatic hernia & 1 & 0.91 \\
\hline Gastrochisis & 1 & 0.91 \\
\hline Omphalocele & 2 & 1.82 \\
\hline Cystic hygroma & 2 & 1.82 \\
\hline Hydronephrosis & 1 & 0.91 \\
\hline Renal agenesis & 1 & 0.91 \\
\hline Down s syndrome & 3 & 2.73 \\
\hline Anophthalmos & 1 & 0.91 \\
\hline Absent distal forearm and hand & 1 & 0.91 \\
\hline Sacrococcygeal Teratoma & 2 & 1.82 \\
\hline Cleft lip, Palate & 4 & 3.64 \\
\hline Microtia & 1 & 0.91 \\
\hline Polydactyly & 1 & 0.91 \\
\hline Genu Recurvatum & 1 & 0.91 \\
\hline Ambiguous Genitalia & 1 & 0.91 \\
\hline Trisomy D & 1 & 0.91 \\
\hline Image Syndrome & 1 & 0.91 \\
\hline Hydrops Fetalis & 2 & 1.82 \\
\hline CTEV & 5 & 4.55 \\
\hline Cleft palate+pierre robin syndrome & 1 & 0.91 \\
\hline NTD+genu recurvatum & 1 & 0.91 \\
\hline $\begin{array}{l}\text { Medulloblastoma+hydrocephalus+pie } \\
\text { rre robin syndrome }\end{array}$ & 1 & 0.91 \\
\hline $\begin{array}{l}\text { Undescended } \\
\text { testes+micrognathia+high arch } \\
\text { palate+CTEV }\end{array}$ & 1 & 0.91 \\
\hline NTD+diaphragmatic hernia & 1 & 0.91 \\
\hline $\begin{array}{l}\text { Mcdk+microceohaly+micrognathia+p } \\
\text { ectus carinatum+CTEV+JT stiff }\end{array}$ & 1 & 0.91 \\
\hline $\begin{array}{l}\text { NTD+ CTEV+ microgenitals+ varied } \\
\text { digit no. }\end{array}$ & 1 & 0.91 \\
\hline OEIS complex & 1 & 0.91 \\
\hline Teratoma+NTD+pleural effusion & 1 & 0.91 \\
\hline Omphalocele+pierre robin syndrome & 1 & 0.91 \\
\hline $\begin{array}{l}\text { Cleft lip+palate+tracheal } \\
\text { atresia+polydactyly }\end{array}$ & 1 & 0.91 \\
\hline $\begin{array}{l}\text { Dextrocardia+cong. diaphragmatic } \\
\text { hernia }\end{array}$ & 1 & 0.91 \\
\hline Microphthalmia+micro cornea & 1 & 0.91 \\
\hline Meningomyelocele+CTEV & 3 & 2.73 \\
\hline $\begin{array}{l}\text { Undescended testes+abdominal } \\
\text { distension+microphthalmia }\end{array}$ & 1 & 0.91 \\
\hline Microcephaly+VSD & 1 & 0.91 \\
\hline $\begin{array}{l}\text { NTD+achondroplasia+VSD+micrope } \\
\text { nis+undescended testes }\end{array}$ & 1 & 0.91 \\
\hline Total & 110 & 100 \\
\hline
\end{tabular}


In the present study, maximum number 27 (24.55\%) of congenital malformations were of Nervous system. 21 (19.09\%) of GI System, 15 (13.64) of CVS, 14 (12.73\%) of MSS, $2(1.82 \%)$ of Urinary system and $1(0.91 \%)$ of genital system, $4(3.64 \%)$ of ear, eyes, face, neck and others were 26 congenital malformations.

In the present study, majority of congenital malformations were seen as NTDs $(24.55 \%)$. Among the NTDs, anencephaly are maximum (14.54\%). Second most common is CHD (13.64\%).

\section{DISCUSSION}

During this study, total deliveries were 9014 and total CMs were 110. The incidence of CM at SGMH and associated hospitals, Rewa was $1.22 \%$, which is similar to incidences $1.21 \%$ and $2.2 \% .^{17,18}$

In 2014, Basavanthappa et al, did a study between 2012 and 2014, reported that incidence of malformations among live births $2.72 \%$ whereas it was $17.33 \%$ among still born babies, which is in concordance with this study which shows CMs were more in still births $(8.17 \%)$ than live births $(1.02 \%) .{ }^{19}$

In the present study, maximum women who delivered babies with $\mathrm{CMs}$ were in the age group of $>40$ years $(8.33 \%),<20 \mathrm{yrs}$ were $5.88 \%, 21-30 \mathrm{yrs}$ age group had $1.40 \%$ and least in $31-40$ yrs $(0.42 \%)$ age group. Similar to a study conducted by Lisa on CM. ${ }^{20}$

In the present study, CMs were more common in Muslim religion $(3.41 \%)$ than in Hindu religion (1.15\%). Similarly Dr. Chowdhury found that most of the respondents were Muslims (91\%); followed by Hindus $(6.4 \%)$; Christians $(1.5 \%)$ and Buddhists $(0.4 \%) .{ }^{21}$

In the present study, CMs were seen more in multigravida $(1.64 \%)$ than primipara $(0.94 \%)$. This is because house wives didn't have media exposure and awareness about the antenatal check-ups and prenatal screening and about the folic acid intake in first trimester, similar to Dr. Chowdhury's study where $30 \%$ of mothers had parity of $2,29.6 \%$ had $3 ; 20.2 \%$ had $4 ; 16.9 \%$ had 1 , while $3.4 \%$ had parity of 5 and more. ${ }^{21}$

In the present study, unbooked women had maximum number of congenital malformations $1.46 \%$ (102) than in booked women $0.39 \%$ (8). Similar to study by B Mahadevan et al, the increasing frequency of NTD $s$ in the hospital based data was probably due to large no. of babies $(70.3 \%)$ born to unbooked mothers. ${ }^{22}$

In the present study, among various risk factors studied, $10(9.09 \%)$ women had fever, 81 (73.64\%) women didn't take Folic acid, $1.82 \%$ (2) with Hypertension and 4 $(3.64 \%)$ with Diabetes Mellitus, $9(8.18 \%)$ gave h/o taking drugs in the present pregnancy, 2 (1.82\%) with Epilepsy, 2 (1.82\%) with Rh incompatibility. Dr.
Chowdhury found that $69.3 \%$ women did not take iron, folic acid and vitamin $\mathrm{B}_{12}$ during pregnancy. $30.7 \%$ took iron, folic acid and vitamin $\mathrm{B}_{12}$ supplementation during pregnancy. He found $88.4 \%(n=236)$ of the respondents did not report of having any disease during pregnancy while the disease status of $3 \%$ were not known. $3.4 \%$ reported of having Hypertension during pregnancy; $3 \%$ were Diabetic; $1.1 \%$ had epilepsy; and $1.1 \%$ had Asthma. Regarding maternal infections during pregnancy $80.1 \%$ did not report of any infections, while the status were unknown for $19.9 \%$ of the mothers. ${ }^{21}$

In the present study, out of 110 congenitally malformed babies, $10 \%$ mothers had consanguineous marriage and $90 \%$ had non-consanguineous marriage $(\mathrm{p}=0.000001$ $\mathrm{X}^{2}=140.80$ ). out of 11,9 were born to Muslim mothers. Similarly, Patel et al, reported that Consanguinity was found in $8.1 \%$ of all congenitally malformed babies. ${ }^{23}$ In this study, out of 11 congenitally malformed babies born to consanguineous parents, $4.55 \%$ had $\mathrm{CM}$ in CVS system, of which $2.73 \%$ were PDA and $1.82 \%$ were VSD. $0.91 \%$ had CNS involvement as Hydrocephalus, Encephalocele, $0.91 \%$ had MSS involvement as absence of distal forearm and hand, $0.91 \%$ with Imperforate anus, $0.91 \%$ with Hydronephrosis, $0.91 \%$ with TGA and PS, $0.91 \%$ with trisomy D. Similar to Dr Chowdhury's study where babies with CAs born to consanguineous parents showed the following pattern of anomalies: Hypospadias $(n=2)$, undescended testicles $(n=2)$, Down's syndrome $(n=1)$, epispadias $(n=1)$, indeterminate sex / ambiguous genitalia $(n=1)$, tetralogy of fallot $(n=1)$ and ventricular septal defect $(n=1) .^{21}$

In the present study, $1.82 \%$ were on AntiEpileptics (phenobarbitone and phenytoin) and $1.82 \%$ were on antihypertensives (name of antihypertensive not known), $3.64 \%$ were on Oral Hypoglycaemic Drugs, $0.91 \%$ was on NSAID, $6.36 \%$ were on unspecified medication, $8.27 \%$ women did not know if they were taking any medication, $78.18 \%$ did not report of taking any drugs or medications during pregnancy.

Dr. Chowdhury also interrogated the women about drug intake and found $75.3 \%$ did not report of taking any medications during pregnancy. $14.6 \%$ did not know if any medications were taken during pregnancy; $3.0 \%$ reported of taking antihypertensive drugs; $2.6 \%$ reported of taking antibiotics but could not specify the name of antibiotics; $2.2 \%$ took some kind of medication but were unable to specify; $1.1 \%$ reported of taking oral hypoglycemic drugs; $0.7 \%$ took antiepileptic drugs; and $0.4 \%$ took some kinds of anti-asthmatic drugs. ${ }^{21}$

In the present study, maximum number $27(24.55 \%)$ of CMs were of CNS. 21 (19.09\%) of Digestive System, 15 (13.64) of CVS, $14(12.73 \%)$ MSS, 2 (1.82\%) of urinary system and $1(0.91 \%)$ of genital system,4(3.64\%) of Ear, Eyes, Face, Neck and others were $26 \mathrm{CMs}$. (Others include $\geq 2$ system involvement). 
The high CNS anomalies (Figure 1 and 2) could be explained by lack of foods fortified with folic acid, very low periconceptional use of folic acid and poor dietary intake of foods rich in folic acid like vegetables due to poor appetite and nausea occurring in pregnancy.

In the present study, there were 27 NTDs (Figure 1 and 2), 15 CHD, 7 (6.36\%) TOF, 6 (5.45\%) duodenal atresia, 4(3.64\%) Imperforate anus, 1 Diaphragmatic hernia, 1 Gastrochisis (Figure 3), 2 Omphalocele, 2 Cystic hygroma, 1 Hydronephrosis, 1 Renal agenesis, 3(2.73\%) Downs Syndrome, 1 anophthalmos, 1 absent distal forearm and hand, 2 Sacrococcygeal Teratoma, 4 cleftlip and palate, 1 microtia, 1 Genu recurvatum, 1 Ambiguous genitalia, 1trisomy D (Figure 4), 1 IMAGe syndrome, 2 Hydrops fetalis (Figure 5), 5 CTEV (4.55\%), 1 cleft palate+Pierre Robin Syndrome, 1 NTD+Genu recurvatum, 1 Medulloblastoma+ Hydroccephalus+ Pierre Robin Syndrome, 1 undescended testes+ micrognathia+ pectus carinatum $+\mathrm{CTEV}+$ joint stiffness, 1 OEIS complex, 1 NTD+CTEV+microgenitals+varied digit No., 1Teratoma+NTD+pleural effusion, 1 Omphalocele+ Pierre Robin Syndrome, 1 cleft lip+palate+ tracheal atresia+ polydactyly, 1 Dextrocardia+ Cong.diaphragmatic hernia, 3 (2.73\%) Meningomyelocele+ CTEV, 1 Microphthalmia+ Microcornea, 1 Undescended testes+ abdominal distension + Microphthalmia, 1 Microcephaly + VSD, 1 NTD + Achondroplasia + VSD + Micropenis + Undescended testes.

Dr. Chowdhury, Out of the 267 cases of CAs, congenital hydrocephalus was the most common accounting for $8.6 \%(n=23)$ of the cases. This was followed by Hypospadias $7.9 \% \quad(n=21)$; Hirschsprung's disease /Aganglionosis / Congenital (aganglionic) Megacolon $7.5 \%(n=20)$; cleft lip/palate 6.7\% $(n=18)$; Gastroschisis $6 \%(n=16)$; other anorectal malformations $4.5 \%(n=12)$; polydactyly $4.5 \% \quad(n=12) ;$ Down's syndrome $4.1 \%$ $(n=11)$; VSD3\% ( $n=8)$; Congenital absence, atresia and stenosis of anus with fistula $3 \%(n=8)$; Turner's syndrome $3 \%(\mathrm{n}=8)$; Congenital hypertrophic pyloric stenosis $2.6 \%$ $(\mathrm{n}=7)$; Atrial septal defect $2.6 \%(\mathrm{n}=7)$; meningocele $2.2 \%$ $(n=6)$; congenital absence, atresia and stenosis of small intestine $2.2 \%(n=6)$; undescended testicle $2.2 \% \quad(n=6)$; Congenital umbilical hernia $1.9 \% \quad(n=5)$; neonatal intestinal obstruction $1.9 \% \quad(n=5)$; Congenital absence, atresia and stenosis of anus without fistula / imperforate anus $1.9 \% \quad(\mathrm{n}=5) ;$ Meningomyelocele $1.9 \% \quad(\mathrm{n}=5)$; encephalocele $1.5 \%(n=4)$; Spina bifida $1.5 \% \quad(n=4)$; Tetralogy of Fallot $1.5 \%(n=4)$; other congenital heart diseases $1.5 \%(n=4)$; Congenital hydrocele $1.5 \%(n=4)$; eventration of diaphragm $1.5 \%(\mathrm{n}=4)$; Cystic hygroma $1.1 \%(\mathrm{n}=3)$; club foot $1.1 \%(\mathrm{n}=3)$; Cloacal anomaly $1.1 \%$ $(n=3)$; Congenital tracheo- esophageal fistula $1.1 \%(n=3)$; Choanal atresia $1.1 \%(n=3)$; TGA $1.1 \%(n=3)$; meconium ileus $0.7 \%(n=2)$; exomphalos, omphalocele $0.7 \%(n=2)$; Congenital absence, atresia and stenosis of rectum without fistula / Imperforate rectum $0.7 \% \quad(n=20$; Epispadias $0.7 \%(\mathrm{n}=2)$; indeterminate sex, unspecified ambiguous genitalia $0.7 \% \quad(n=2)$; Congenital posterior urethral valves $0.7 \%(\mathrm{n}=2)$; Congenital hydronephrosis $0.7 \%(n=2)$; and conjoined twins $0.7 \%(n=2){ }^{21}$

In the present study, women from rural area had more congenitally malformed babies $(1.34 \%)$ than urban area $(0.47 \%)$. Sadet et al, found that there was an increase over time regarding the proportion of newborns with birth defects pertinent to rural areas of Elbasan region than urban areas $(\mathrm{p}=0.04) .{ }^{24}$

\section{CONCLUSION}

During this century, as a result of the improvements in hygiene and health care, there has been a steady decline in the contribution of environmental factors to diseases, communicable diseases and malnutrition have changed the disease spectrum in general population. Hence, as a result, congenital and hereditary diseases have been recognized as being the major health burden.

Various factors, which influence the frequency of congenital malformations are, maternal age, drug intake, fever, alcohol consumption, h/o abortions, consanguinity and genetic abnormalities in the parents or the gametes. Therefore, it can be concluded that many malformations arise because of the interplay of genetic, environmental and multifactorial factors.

Some environmental factors may be causing genetic damage in the gametes of the parents, alter the tissue growth and interfere with the cellular differentiation, causing malformations in the newborns. The stress imposed on the parents may be reduced considerably by understanding the causes of the malformations and adopting the management strategies outlined for the prevention or reduction of congenital malformations.

CMed neonates often require intensive, multidisciplinary medical treatment, which is always costly and frequently life threatening. However despite massive advancements and refinements in the study of congenital anomalies, the magnitude of the problem still to this day causes significant health impacts.

We hope that observations of our study will be clinically useful to physicians and obstetricians enabling them to optimise treatment modalities for pregnancies with CMs in order to achieve a healthy mother and a healthy baby.

Funding: No funding sources

Conflict of interest: None declared

Ethical approval: The study was approved by the Institutional Ethics Committee

\section{REFERENCES}

1. Spranger J, Benirschke K, Jail JG. Errors of morphogenesis, concepts and terms. J Pediatr. 1982;100:160-5. 
2. Congenital Anomalies. WHO Fact sheet N370, October 2012.

3. Merchant SM, Indian Council of Medical Research, Genetic Research Centre, Bombay Annual Report; 1989: 27.

4. Singh M. Hospital based data on perinatal and neonatal mortality in India. Indian Paedtr. 1986;23:579-84.

5. Mishra PC, Bhaveja R. Congenital Malform in newborn-A prospective study. Indian Pediatr. 1989;26:32.

6. Verma M. Chaatwal J, Singh D. Congenital malformations- a retrospective study of 10,000 cases. India J Paediatr. 1991;58:259-63.

7. Bhat BV, Ravikumar M. Perinatal mortality in India -Need for introspection. Indian J Martin Child Health. 1996;7:31-3.

8. Agarwal SS, Singh U, Singh PS, Singh SS, Das V, Sharma A, et al, prevalence and spectrum of congenital malformations in a prospective study at a teaching hospital. Indian J Med Res. 1991;94;413-9.

9. World health organization. Management of birth defects and haemoglobin disorders: Report of a Joint WHO-March of Dimes meeting. Geneva, Switzerland, Geneva: WHO; 2006.

10. Christianson AL, Modell B. Medical Genetics in Developing Countries. Annual Rev Genom Human Genetics. 2004;5:219-65.

11. Diav-Citrin O, Koren G. Nausea and Vomiting of Pregnancy: State of the Art 2000. Toronto, Ontario, Canada: The Motherisk Program, the Hospital for Sick Children; 2000.

12. Bhide P, Sagoo GS, Moorthie S, Burton H, Kar A. Systematic review of birth prevalence of neural tube defects in India. Birth Defects Res A Clin Mol Teratol. 2013;97:437-43.

13. Stevenson RE, Hall JG. (eds). Human Malformations and Related Anomalies. Oxford University Press, New York; 1993:115.

14. Sharma R. Birth defects in India: Hidden truth, need for urgent attention. Indian $\mathrm{J}$ Hum Genet. 2013;19(2):125-9.
15. Smith DC, Dewey WJ. The emergence of congenital malformations as a publication health problem. In: Development of community health service for children with congenital anomalies. Ann Arbor, Michigan, 1964.

16. Warkany J. Congenital malformations in the past. J Chron Dis. 1959;10:84

17. Munjal P, Thakkar J. Study of gross congenital malformations in newborn. JEMDS. 2013;2(27):4988-93.

18. Neelakandan, Pugazhendh. Pattern of Congenital Malformations in Newborn. Dept. Of Paediatrics, Coimbatore: E J Tamilnadu Dr. M.G.R medical university. 2011:1-3.

19. Basavanthappa SP, Pejaver R, Srinivasa V, Raghavendra K, Suresh Babu MT. Spectrum of congenital malformations in newborns. Int $\mathrm{J} \mathrm{Adv}$ Med. 2014;1(2):82-5.

20. Lisa M, Hollier, Kenneth J, Kelly MA, Cunningham FG. Maternal Age and Malformations in Singleton Births. Obste Gynaecol. 2000;96:701-6.

21. Chowdhury FMB. Spectrum of Congenital Anomalies among Children Attending the Pediatric Departments of Dhaka Medical College Hospital. IOSR J Dent Med Sci. 2014;13(2):4.

22. Mahadevan B, Bhat V. Neural tube defects in Pondicherry. Indian J Pediatr. 2005;72(7):557-9.

23. Patel ZM. Birth Defect Surveillance study. Indian J. Paediatr. 2005;72(6):489-91.

24. Gjata S, Roshi E, Gjata A, Burazeri G. Magnitude of Birth Defects In Elbasan Region, Albania, For The Period 2003-2013. Managmt health. 2014;18(2):3941.

Cite this article as: Naik M, Bhargava M, Yadav K. Epidemiological study of congenital malformations at birth in a tertiary health centre in central India. Int J Reprod Contracept Obstet Gynecol 2018;7:284551. 